\title{
Publisher Correction: Programmed death ligand 1 signals in cancer cells
}

\author{
Anand V. R. Kornepati, Ratna K. Vadlamudi and Tyler J. Curiel(i)
}

Correction to: Nature Reviews Cancer https://doi.org/10.1038/s41568-021-00431-4, published online 14 January 2022.

This article was originally published with the title 'Programmed cell death 1 ligand 1 signals in cancer cells'. This has been corrected in the HTML and PDF versions of the article to reflect the more common usage of the definition of PDL1 as 'programmed death ligand 1'. In addition, the definitions for the acronyms PD1 (programmed death 1) and PDL1 have been added to the abstract, the introduction and display items of the article.

https://doi.org/10.1038/s41568-022-00445-6 I Published online 19 January 2022

๑) Springer Nature Limited 2022 